\title{
Velyaminov-Zernov V. V. and His Contribution to the Study of Historical Sources of Moslem Peoples
}

\author{
Ramil M. Valeev ${ }^{1}$, Firdaus G. Kalimullina ${ }^{1} \&$ Rafael M. Valeev ${ }^{1}$ \\ ${ }^{1}$ Kazan (Volga region) Federal University, Kazan, Russia \\ Correspondence: Ramil M.Valeev, Kazan (Volga Region) Federal University, 420008, Kazan, Kremlyovskaya \\ street, 18, Russia. E-mail: valeev200655@mail.ru; ram.valeev2016@yandex.ru
}

Received: June 2, 2015 Accepted: June 15, 2015 Online Published: June 29, 2015

doi:10.5539/jsd.v8n5p26 URL: http://dx.doi.org/10.5539/jsd.v8n5p26

\begin{abstract}
The study of trends and outcomes in the development of modern Oriental historiography and source studies involves the study of scientific heritage and contributions of previous generations of scientists. Among those Russian and European orientalists of the XIX century, who made a great contribution to the development of the Russian Science of history and Oriental Studies, a special place is occupied by the Academician Vladimir Velyaminov-Zernov. Until today, the scientific heritage of V. V. Velyaminov-Zernov remained poorly studied. The main purpose of the article is to identify the contribution of V. V. Velyaminov-Zernov to the study of the history of the Turkic peoples and the medieval Muslim Khanates that emerged on the territory of modern Russia after the collapse of the Golden Horde. This article describes the results of research trips and archeographic work of V. V. Velyaminov-Zernov in different periods of his life. The main attention is paid to the Muslim narrative and epigraphic monuments, which were first introduced by him into scientific circulation. Analysis of his work allowed to define the views of Vladimir Velyaminov-Zernov on the continuity of ethno-cultural and religious traditions of the Muslims of the Middle Volga region, southern Urals, Urals, Central Asia and the Middle East.
\end{abstract}

Keywords: Oriental study, Turkology, V. V. Velyaminov-Zernov, Moslem, narrative sources, Turko-Tatar epigraphic monuments, tarkhan certificate (paper)

\section{Introduction}

Vladimir Vladimirovich Velyaminov-Zernov (1830-1904) is the largest Russian orientalist, writer, researcher of historical sources, academician (1861, 1990 honorary member), doctor of the Turkish-Tatar literature (1866). The scientist studied the history of the Moslem peoples of the Volga region, Central Asia and the Middle East (Avrasya türkologları sözlügü. Rusya türkologları, 2011), he revealed the most important Moslem narrative sources in Russian and foreign archives, researched Turko-Tatar epigraphic monuments, compared them with the data of Russian Chronicles, gave them an objective assessment.

In 1850-1859 V. V. Velyaminov-Zernov worked as a translator in the Asian Department of the Ministry of Foreign Affairs. In 1851-1856 he was on a scientific business trip in the Orenburg region, studied the language and customs of the Kazakh people. Simultaneously with his research activities Velyaminov-Zernov was involved into scientific-organizational work. In 1857-1881 he was an active member of the Russian archaeological society, in 1881 he became an honorary member, in the period of 1861-1872 he occupied the post of the Secretary of the Russian archaeological society. In 1864-1872, he edited the Journals "Trudy (Works) of the Eastern branch of the Russian archaeological society" and "Izvestia of the Russian archaeological society". From 1855 to 1898,22 volumes of the scientific works of the Eastern branch of the Russian archaeological society were published. More than one-third of the archaeological society publications were produced under the editorship of V. V. Velyaminov-Zernov. In 1872 he stopped his research activities for bad health reason. In the period of 1879-1888, V. V. Velyaminov-Zernov headed the local nobility of the Oryol Province (Maloarhangelskiy district).

In the period of 1888-1902 he was a Trustee of the Kiev educational district; at the same time, since 1889 he occupied the post of the Chairman of the Commission for studies of ancient documents in Kiev, Podolsk and Volyn provinces. In 1902 he became an Actual privy councilor.

V. V. Velyaminov-Zernov was a member of Literature and History Division of Asian peoples at the 
historical-philological Department of St. Petersburg Academy of Sciences. The scientist was regularly elected to the Commission on awards to scientists, and to the Commition involved in reviewing new research works. In the nineteenth century thanks to such review Commissions many new research works on historiography and source studies appeared. They also haven't lost their significance today (Velyaminov-Zernov, 1859).

Numerous research business trips that were organized by St. Petersburg Academy of Sciences and Russian archaeological society, gave V. V. Velyaminov-Zernov an opportunity to get acquainted with life, customs and languages of the Moslem, Turkic peoples of Russia and Central Asia. It is during such trips that the scientist collected valuable sources and studied epigraphic monuments.

\section{Methodological Framework}

Methodology of this research is based both on traditional and secondary research methods. Fundamental methods of the research work are comparative-historical and historical-genetic. They reveal the evolution of V.V. Velyaminov-Zernov views on the objects of his research and help to determine the level of his contribution to the source studies, historiography and historical science in general. It should be noted that the comparative-historical method was used as in diachronic (compared to predecessors of V. V. Velyaminov-Zernov) and synchronous (comparison with his contemporary researchers). The problem-chronological method promotes consistent coverage of the views of the scientist. Epistemological, logical principles and method of system approach helped to define role and importance of the main problems covered by Velyaminov-Zernov. Reconstruction method solves the problem of reconstructing the sequence of events that constitutes the real content of the historical process, which is important when analyzing the works of the scientist. This, in turn, allows to identify the objectivity and subjectivity of Velyaminov-Zernov's opinions. Linguistic research methods helped to determine the specifics of the XIX century scientific style and the personal scientific research style of scientist. The usage of different methods brought about proper notion of V. V. Velyaminov-Zernov's scientific work, the peculiarities of his scientific developments and possibility to assess the level of their novelty.

\section{Results}

V. V. Velyaminov-Zernov introduced to scientific use a huge varaity of Turkic sources, revealed some important documents.

In the early 1850s the turkologist discovered some tarkhan documents in the Archive of the regional Board of Orenburg Turkic Kazakhs, on the basis of which he later published a paper "Sources for study of the tarkhan granted to the Bashkirs by Russian tsars" (1864). Before him a series of works about tarkhan executive orders had been already published. The work of I.N. Berezin enjoyed special prestige (Berezin, 1850).

V. V. Velyaminov managed to prove the fact that in Russia tarkhan certificats had still been granted even in the second half of the eighteenth century. Prior to that it was considered that tarkhan privilege had been destroying since 1559 during the reign of the tsar Fyodor Ioanovich, then it was temporarily abolished in 1672 by Alexey Mikhailovich, and finally by Peter I.

Firstly, V. V. Velyaminov-Zernov expanded the list of persons whom Tarkhan privileges were given in Russia. That title was granted to Bashkir citizens of the Ufa uyezd by the sovereigns, usually, they were the Bashkirs who participated on the side of the Russians in various wars and translators from Oriental languages in the offices. In such cases, simple yasak Bashkirs were attributed to "sluzhiliye ludy" - a category of people in state service (military, administrative, etc).

Secondly, the scientist had rejected the assertion of I. N. Berezin that tarkhan privileges were cancelled at the beginning of the XVIII century.

In the archive of the regional Board of the Orenburg Kirghiz (Kazakhs) V. V. Velyaminov-Zernov found a document dated back to 1777 "On the cancelation of the sergeant Yusuf Nadyrov of per capita salary, and ranking him as a tarkhan" ; and the delivery of information about the number of tarkhans ". In its time it was that very document that provided an occasion for identifying the tarkhans lived in Orenburg province. V. V. Velyaminov- Zernov discovered those documents and put them into scientific usage. From the sources quotedted in the publication of V. V. Velyaminov-Zernov it is quite obvious that tarkhan certificates were given up to 1777 whereas the tarkhan privilege was officially observed until 1754 only, when the tribute (yasak) was replaced by a tax on salt, which tarkhans were also obliged to buy. Since then, the title of a tarkhan became just nominal, although traditionally it was granted till the end of the XVIII century. It should be noted, that the main part of tarkhan certificats had been granted before the creation of the Orenburg line (up to 40-ies of the XVIII century), apparently, it was one of the measures to attract representatives of non-Russian peoples of the South-Eastern outskirts of Russia to the Russian service. 
Documents published by Velyaminov-Zernov, refuted another assumption of I. N. Berezin. The predecessor wrote that all tarkhans were of the same rank. From tarkhan serticates, granted to the Bashkirs, it became clear that in Russia there were several types of tarkhans. Someone was fully exempted from a tax, someone partially. Someone had juridicial immunity, someone didn't. Basically, tarkhan certificate was granted «forever», i.e., the title was given even to the descendants; however, the title was not always hereditary. Moreover, in different years tarkhan privileges were different. Every year the range of those privileges reduced.

It is obvious that the publication of V. V. Velyaminov-Zernov on Bashkir tarkhans introduced some novelty into the problem of tarkhan certificates. On the basis of the revealed sources, the scientist managed to prove the fact that tarkhan certificates were also granted in Russia even in the second half of the eighteenth century, that the number of persons whom tarkhan certificates were given was much bigger in reality and that several types of the tarkhan existed there.

In the same archive V. V. Velyaminov-Zernov discovered an important source for the history of the Bukhara khanate and some neighbouring countries - "Abdullah-nama" ("the Book of Shah nobility") (the end of the XVI the beginning of the XVII centuries) by Hafiz of Tanisha, who was a contemporary of Abdullah Khan. That source had long been looked for by scientists; that finding was also very valuable for the St. Petersburg Academy of Sciences. Later the source was kept personally by V.V. Velyaminov-Zernov (Veselovsky, 1887). The source allowed scientists to reconstruct the best sequence of Bukhara khans reign up to the beginning of the XVII century

In Orenburg region V. V. Velyaminov-Zernov also investigated epigraphic monuments of the Urals. In 1856 he published his article "The Monument in Bashkiria with the Arab-Tatar inscription on it which described the mausoleum (cashana) of Hussein Bey, the XIV century preacher of Islam (it is located close to Ufa). While travelling across the Kazakh steppe the scientist got in the hands the rewritten copy of that inscription made in cyrillic in 1845 by some Yumatov. V. V. Velyaminov-Zernov made his own transcription of the text. He described the location and the exterior of the mausoleum, noted that a Moslem cemetery situated nearby the monument was older than the monument itself. The monument to Hussein Bey was rebuilt in 1901, and its original appearance must had been changed. So, in this respect the research of V. V. Velyaminov-Zernov is of particular value.

Comparing the design traditions of the architectural monuments of Ufa and the Middle Volga region, he suggested that Islam came to the Bashkirs from the Volga Bulgaria. Considering that problem, V.V.Velyaminov-Zernov came across the text source of Hishamuddin bin Sharafutdin Bulgari-Muslimi "Tavarikh and Bulgaria" (the end of the XVIII century), in which the city of Bulgar was described as the center from which Islam entered Ufa and other areas. The scientist made his own more accurate translation of "Tovarikh and Bulgaria".

Studying the tombstones of the Kazakh steppes on the shores of the Syrdarya, V.V.Velyaminov-Zernov came to the conclusion that the spread of Islam in Western Kazakhstan was also due to the Bulgar influence (Velyaminov-Zernov, 1859). Furthermore, the scientist revealed Bulgarian traditions while studing the Moslem monuments of the Middle East (now it's the territory of modern Afghanistan). He considered the enormous size of burials in the tombs (up to 4 meters in length) to be one of their distinctive peculiarities The turkologist noticed that the trend was observed not only in the design of the graves, but in folk legends as well, which often mentioned the giants (Zemlevedenie K.Rittera, 1867).

At the end of the 1850s in the archive of the Ministry of foreign Affairs V. V. Velyaminov-Zernov found a Mongolian chronicle by the anonymous author of the XVII century "Altan Tobchi" ("Golden arch"), which, with the involvement of more ancient chronicles, narrated the story of the Mongol khans (Veselovsky, 1904). That source is a unique heritage of the Mongolian historiography. The fact that the name of the discoverer of "Altan Tobchi," is not mentioned in Soviet historiography, that the name of V.V. Veliaminov-Zernov is left aside draws attention (Sovetskaja istoricheskaja jenciklopedija, 1961). The text "Altan Tobchi", translated by G. Gomboev, was published in 1858 (Anonimnaja - Altan Tobchi, 1858).

In the early $1860 \mathrm{~s} \mathrm{~V}$. V. Velyaminov-Zernov was the first to publish the original text of the most important source in Kurds history - "Sharaf-nama" (the end of the XVI century), written by Kurdish Khan Sharaf Bidlisi (Velyaminov-Zernov, 1860, 1862). In the nineteenth century, many European scientists showed their interest in that source; the contribution of V. V. Velyaminov-Zernov in its scientific study is obvious (Pamjatniki pis'mennosti Vostoka. Sharaf-name, 1967). Preparing publication of the text, in summer 1860, V. V. Velyaminov-Zernov visited France for verification of the Iranian written copy of the source "Sharaf-nama" (purchased in 1854 by N.V. Khanykov, Russian General Consul, a cousin of V. V. Velyaminov-Zernov) with the 
Paris one, which was kept in the Imperial (National) library. The same year the scientist refered to the Isfehan written copy of "Sharaf-nama" stored in London's British Museum (Zapiski IAN, 1868).

The publication of "Sharaf-nama" was especially warmly taken in Moslem countries. In 1868, given the value of the work, the Turkish government, awarded V.V.Velyaminov-Zernov the order of Medgidia of the 3rd degree. In 1869 the Persian Shah granted the scientist the order of the Lion and the Sun of the 2nd degree with a star (RGIA, f. 733 , op. 121, D. 323, L. 7.).

After the publication of the Persian text "Sharaf-nama" had been done the corresponding member of Petersburg Academy of Sciences F. N. Sharma translated it into French (Charmoy, 1868, 1870, 1873, 1875). V. V. Velyaminov-Zernov reviewed both volumes; he was a scientific editor of the 1st volume, the 1st and the 2nd parts of which were published in 1868, 1870. In 1931 in Cairo a researcher Muhammad Ali Awni made the second edition of the Persian text "Sharaf-nama". At the beginning of the book he placed the Arabic translation of the Preface, made by V. V. Velyaminov-Zernov, thereby underlining the contribution of the Russian orientalist into the study of this source (Encyclopaedia of Islam, 1986).

V. V. Velyaminov-Zernov studied in detail the inscriptions on the monuments and the formation schemes of epigraphic monuments of the Kasimov khanate, located in the Ryazan region. That became the core for his fundamental work "the Study of the Kasimov kings and princes" (Velyaminov-Zernov, 1863-1887), which also showed in detail the history of the Golden Horde and postgoldenhord Tatar khanates (Kalimullina, 2014). In that work the scientist had analyzed such Moslem written sources as "Sheibani-nama" (XVI century), "Compendium of Chronicles" (1602) by Kadir-Ali-Bek, "Assab as-Saar" ("Seven planets") (the middle of the XVIII century) by the Crimean historian Muhammad Riza, "Tarikhi Rashidi" (1541-1547) by the persian author Muhammad Haydar, "Baburname "(1520s) by Zahreddine Babur, a cousin of Muhammad Haydar, "Shagari Turks" (XVII century) by Abulgazi, "Tazkira and Hadigan" (1768-1769,) by Muhammad-Sadiq Kashgari. The sources contain enomous information on the Turk-Tatar khanates and present shajarahs of the famous historical figures.

V. V. Velyaminov-Zernov discovered and analyzed the spiritual Testaments of such Kasimov residents of the XVII century as Galik-Atalik and Kishbik-Bikach. These survived Tatar acts are very rare sources and they are of great scientific value.

V. V. Velyaminov-Zernov was the first to put forward a number of significant challenges in the history of postgoldenhorde Tatar khanates. When initially studing the history of Kasimov khanate Velyaminov-Zernov was under the influence of the generally accepted concepts of the role of the khanate. By that time the opinion had been formed that Basil II, pursuing his goals to defend the Russian lands from the nomads and to conquer the Tatar khanates, granted a visiting Prince Kasim a small town of Meshchersky, who in turn had become "subordinated to the Grand Duke by military duty". First of all, the scientist tried to explain the term "Kasimov Kingdom", that was not done by his predecessors.

Describing the history of the Kasimov khanate, V.V. Velyaminov-Zernov drew parallels with other Turkic-Tatar state formations of that period, established their common traditions and came to the conclusion that the Kasimov khanate structure was a copy of the Kazan khanate. The scientist noticed that in different years there were rather controversial relationships between the Russians and Kasimov rulers and that sometimes they could even reach alliances. But that point was not fully developed by him. His conclusions greatly contradicted to the originally proposed concept of the history of the Kasimov khanate. It is obvious that the author himself appeared to be in a predicament: the original concept of the problem was left by him, but to develop a new one he was not ready yet. This, probably, explains the lack of proper interpretation of some issues and contradictions in his work. The fact that before V.V. Velyaminov-Zernov many problems were not identified at all or were studied partially and weakly, his work acquired particular value and served as the starting point, the main base for the researchers of future generations.

The scientist's doubts about the oficially accepted vertion of the Kasimov khanate formation introduced some novelty to the problem. It should be noted that in his work V. V. Velyaminov-Zernov did not specify the exact date of the Kasimov khanate foundation, taking only a certain period of time, he concedeCrimea, were also privileged in Kazan and Kasimov. But by the seventeenth century the number of kins had increased up to five in the Crimea: Shirin, Mangyt, Sigut, Argyn, Baryns, and in the XVIII century the kin Mangyt was squeezed by the kin Mansur. In Kazan they were later complemented with the kin Mangyt. As for Kazan the scientist traced the title «prince above princes», i.e., beglerbeg as «the main Karachi». In Kasimov it was possible to learn about the ruling kins only through the pictures of the Kasimov throne during the ceremony of enthroning of Uraz-Muhammad in 1600. There were the kins of Argyn, Kipchak, Mangyt and Jalair. But in a document dated 1563 the kin of shirin was also mentioned in Kasimov (Velyaminov-Zernov, 1866). The scientist pointed out that 
perhaps the kin of Jalair had squeezed the kin of Shirin. Among the kins of Shirin and Mangyt of the Crimean khanate and the Nogai Horde, the author highlighted the titles of kalga, kick-buoys, nureddin (nuradin), kay-kuvat and tabuga. Nureddin was the second person after the Prince. Under the status Nuretdin was followed by two other kins - Kay-kuvat and Taboga,and moreover, the latter was only mentioned in the latest documents. The auther didn't give the designation of the term "kick-buoys".

The scientist explained in detail the ttitles of atalik, imeldash and seids - the descendants of the prophet Muhammad. In some studies seids were considered only spiritual persons. On this occasion, the author noted that in Kazan that word had special impotence; the head of the local clergy was also called so. Most likely, he was a descendant of Muhammad. (Velyaminov-Zernov, 1863). He thought that in Kasimov Seid was apparently a military leader, so as he had not only special court and the regiment. . To the class of "spiritual persons and scientists," he reckoned mullahs, danishmends and khafizes. Danishmends were teachers, mentors in madrasahs (current mudarrisi), hafizes - special persons having spiritual ranks, from which the the word "Abyz"was formed; No explanations of these titles were given by the scientist.

The scientist had also provided another layer different from the beks and murzas. Those were common tatarscossacks. He didn't explain what kind of social layer it was. He tried to explain the etymology of this word, considering an issue of the Kazakh nation. "The word cossack means: hobo, free man, dashing".

V. V. Velyaminov-Zernov revealed the existence of the slave trading in Kasimov (Velyaminov-Zernov, 1863). Citing the text of the spiritual Testament of Galica-atalyk Velyaminov-Zernov showed that in Kasimov slaves were mainly foreign prisoners of war, they were on the rights of dependent peasants and could obtain their freedom at the requests of their owners. The researcher noted that during his reign in Kasimov Uraz-Muhammad had released many captivity (polonniks) ". The scientist did not explain who he meant by "captivity (polonniks)". It could be foreign prisoners of war, and other slaves, but the Russians were unlikly, because Kasimov rulers were forbidden to keep Russian slaves. However, there were cases when the noble Kasimov tatars had kept Russian women-slaves.

Explanations of the titles' meanings given by V. V. Velyaminov-Zernov had been recognized in scientific circles, and today they are interpreted almost as he did. The contribution of the scientist is quite obvious here. While making research he compared existing Turko-Tatar public entities, established the similarity of the titles, but he didn't ask himself a question: "Why is it so?", "What preceded this or that fact?" Currely it is established that such titles as karachibeck, beclerbeck, atalyk and others had existed since Dzhuchiev Ulus and their roots were traced back to the Great Mongol Empire. After the collapse of Dzhuchiev Ulus those titles were inherited by the newly formed Tatar khanates. V.V. Velyaminov-Zernov didn't share that opinion. However, he was close to that, when analysing the source "Tarikhi Rashidi» he noted that the title ulus-beck (ulugbek), occurring among jagats, ascended to the times of Genghis Khadn.

Having at his disposal a great variety of sources which said about the collection of tribute from Moscow Grand Dukes in favour of the Kasimov rulers the author first began to develop that problem. Taking into account the views of his predecessors and the fact that they had significant contradictions with the sources revealed by V. V. Velyaminov-Zernov it can be assumed that the author was not ready to draw any final conclusions. However, his credit is that he could faithfully present the information he had got in the research process.

Based on the Russian Chronicles, legislation and Turkic sources, V.V. Velyaminov-Zernov clearly traced the process of liquidation of the Kasimov khanate (the introduction of the voivodeship, change of local authorities in Kasimov, the Christianization of the Ryazan region, etc.). He underlined that magistrates had significantly limited the rights of the Kasimov rulers only at the beginning of the XVII century and suggested that the change of Kasimov local authorities occurred in the mid-seventeenth century, during baptism of Seid-Burgan.

In his research V. Velyaminov-Zernov examined in detail the history of the Kazan khanate which had close historical relations with the Kasimov khanate. He traced back the fact of participation of Kasimov Tatars in campaigns against Kazan, noted that during the conquest of Kazan they were in reserve. The scientist gave a psychological characteristic of such famous personalities in the history of the Tatar people, as Suyumbike and Shah Ali. Based upon the above, we can conclude that V. V. Velyaminov-Zernov made an outstanding contribution to the historiography of the Kasimov khanate.

In 1864, under the scientific editorship of V.V.Velyaminov-Zernov the fundamental work based on the sources of the Crimean khanate, which was prepared in 1858 by the the tatar scientist H. Faishanov (Materialy dlja istorii Krymskogo hanstva..., 1864) saw the light The book presents the texts of about 400 tatar documents, contains personal, geographical and terminology indexes. This work still remains the basic material for the source researchers interested in medieval Tatar acts (Usmanov, 1980). These sources are also important for the scientists 
studying international relations of the medieval Turkic states. It is known that it was V.V. Velyaminov-Zernov who translated that book. For that purpose the scientist used to work in the Moscow archive. In particular, there was a need in a more accurate recovery of some Russian and Polish proper names in tatar texts (Sankt-Peterburgskiy filial Arhiva Rossijskoj Akademii nauk, 1859). Unfortunately, his development had not been published. Apparently, it was due to his sudden illness, which manifested itself in the early $1870 \mathrm{~s}$

In 1868 V.V.Velyaminov-Zernov published «Jagadish -Turkish Dictionary". No information survived as far as the author of the manuscript of the dictionary is concerned It is known that he called himself Alai-Ben-Muhibbi-El-Sherif, The date of the dictionary createation was marked as 1560 (Velyaminov-Zernov, 1868). The basis of the dictionary constituted the language of the works of the Central Asian Turkic poet, Sufi direction philosopher Alisher Navoi (1441-1501) - chagatai/old uzbek. The manuscript was called "Chagatai illustrative examples to the language of Navoi". People named the dictionary "Abushka" due to the first word in the text.

V. V. Velyaminov-Zernov said that the dictionary was necessary for better understanding of the works by the best chagatai writers, such as Navoi, Lutfy and Mirhaydar. In introduction to the dictionary the scientist mentioned the preceding six dictionaries to the language of Navoi and praised the work of Hoist Imani Herat "Badai al-lughat" (1501), having called his dictionary a unique monument of the late XV century. Later national historiography noted that "Abushka", published by V.V.Velyamibynov-Zernov was the second valuable source after "Badai al-lughat" for studying the history of old Uzbek language of the Navoi era (Umarov, 1985)

While preparing the dictionary for publication V.V.Velyaminov-Zernov used five manuscripts, which were stored in St. Petersburg - at the Imperial St. Petersburg public library, the Imperial Library of St. Petersburg University, the Asian Museum of the Petersburg Academy of Sciences, Educational Department of Western languages of the Ministry of Foreign Affairs and at the academician B. A. Dorn. It is known that in 1868 the scientist went abroad with the view of verification of the dictionary texts (Zapiski IAN, 1868), but there is no accurate data, which countries he visited. Currently, several manuscripts of the dictionary are kept in the libraries of Paris, London, Tashkent and archives of Turkey. It is known that in 1869 French edition of the dictionary also appeared. (Zapiski IAN, 1868).

For the basis of his edition V. V. Velyaminov-Zernov took the manuscript, kept in St. Petersburg public library, and the text was compared with four other written copies. V.V. Velyaminov-Zernov compared the examples given by the author of the dictionary with the texts of A. Navoi. When creating a dictionary the author used 19 works of A. Navoi. The scientist found out many mistakes made by the author of the dictionary and changes made to the text by V.V. Velyaminov-Zernov were given in brackets so that the reader could distinguish the original and corrected text material. In $1869 \mathrm{~V} . \mathrm{V}$. Velyaminov-Zernov presented his work "The Collection of Kyrgyz-kazaksha adverb" which he had been preparing since 1862 to St. Petersburg Academy of Sciences. Scientists of St. Petersburg Academy of Sciences supported his idea and noted that the work would be interesting both for Russian and European academic world (Zapiski IAN, 1863). The collection includes Kazakh Proverbs, songs and stories accumulated by the scientist during the trip to the Orenburg region in the $1850 \mathrm{~s}$. He made an Appendix which included Russian translation of the Kazakh texts and Kazakh-Russian Glossary. Colleagues of V. V. Velyaminov-Zernov greatly estimated the Glossary, the text of the famous poem "Kozy-Korpesh", that he wrote Arabic script and Its translation into Russian. The researchers assessed the work positively and offered to publish it at the expense of the Academy of Sciences (Zapiski IAN, 1869). Serious illness prevented the publication of the finished text written by V. V. Velyaminov-Zernov. The fate of the manuscript of his Kazah collection is unknown.

V. V. Velyaminov-Zernov was also interested in Islamic numismatics and handwritings on the weapon. In 1859 he published a monograph "Coins of Bukhara and Khiva, in which he discussed the history of Bukhara and Khiva khanates. Thanks to numismatic material some gaps in the sequence of khans reign were filled in. At the 4th international Congress of Orientalists, held in September 1878 in Florence, V. V. Velyaminov-Zernov presented his collection of Oriental arms. The collection comprised Persian arms of the era of the Safavid dynasty (1502-1736,) (Velyaminov-Zernov, 1879).

Until the end of his days V.V. Velyaminov-Zernov gathered collections of Oriental coins and arms. The scientist bequeathed the numismatic collection to Mintz-study of the Hermitage in St. Petersburg after his death (RGIA, f. 468, op. 14, unit HR. 1387, 14 HP).

In 1870 s V.V.Velyaminov-Zernov began to study the sources on the history of the Crimean khanate in the archives of Italy, where, according to him, there was a wealth of material on the history of Crimea and data on the history of the Ottoman Empire. It is known that a significant number of Tatar manuscripts of the past 
centuries came to the libraries of Western Europe through merchants, pilgrims, travelers, and they are stored in the archives of England, Austria, Italy, Hungary, Sweden, France and other countries (Karimullin, 1992). The disease which soon forced him leave science forever prevented V.V.Velyaminov-Zernov from completing the work in Italy. The fact that he had to abandon "the meaning of his whole life" - scientific research made him suffer.

\section{Discussions}

Some aspects of this subject were discussed by Russian specialists.

After the death of Vladimir Velyaminov-Zernov his contemporary N.I. Veselovsky (1904) published a large obituary, where he described in detail the biography of the scientist. M.A.Usmanov (1980) studied some aspects of the scientific heritage of Vladimir Velyaminov-Zernov.However, from this point of view the problem is examined for the first time in Russian and European historiography.

\section{Conclusion}

Oriental sources put into scientific circulation by V. V. Velyaminov-Zernov helped to identify many new facts in the history of the Molem peoples of Russia, Central Asia and the Middle East. Unfortunately, some developments of the scientist had never been published because of the illness, which stoped his research activities. The manuscripts of his unpublished studies were not preserved.

V. V. Velyaminov-Zernov had achieved significant results in the Archeography and source studies. He revealed and published some new tarkhan diplomas granted to the Bashkirs, and so introduced a novelty into consideration of that issue. Through the study of Islamic numismatics the scientist had identified particularity of the historical development of the Central Asian khanates.

V. V. Velyaminov-Zernov had investigated numerous epigraphic monuments, discovered their similarities in different geographical regions, through which he put forward his version of the Bulgarian influence on the spread of Islam in Western Kazakhstan. The orientalist had revealed and published Turkic dictionaries.for future researchers.

V. V. Velyaminov-Zernov first in Russian historiography pointed to the continuity of traditions common for the Golden Horde and the Kasimov khanate. He came to the conclusions which were much contrary to officially accepted at that time version of the origin and status of the Kasimov khanate. That was the reason the scientist couldn't specifically formulate his ideas, but to leave them in the form of reflections for future generations of researchers.

It should be emphasized that the research of the Russian Turkologist in the field of historical sourses has not lost its scientifiic significance up to now. Researchers studying the history of medieval Turko-Tatar States and those who study the history of Islam in the Volga region, the Urals and Central Asia often turn to his writings and publications.

V. V. Velyaminov-Zernov worked fruitfully in the archives of France, England and Italy. The question of further research of Turkic sources stored in foreign archives, remains open today.

The authors express their gratitude to the St. Petersburg branch of the archive of the Russian Academy of Sciences and the Russian historical archive for their support in preparation and implementation of this project.

\section{Acknowledgments}

The work is performed according to the Russian Government Program of Competitive Growth of Kazan Federal University

\section{References}

Anonimnaja - Altan-Tobchi. (1858). Mongol'skaja letopis'v podlinnom tekste i s perevodom Galsana Gomboeva. Trudy Vostochnogo otdelenija Arheologicheskogo obshhestva. Ch.6. Sankt Peterburg.

Berezin, I. N. (1850). Vnutrennee ustrojstvo Zolotoj Ordy (po hanskim jarlykam). Sankt Peterburg.

Charmoy, F. B. (1865-1875). Cheref-nameh ou fastes de la nation kourde par Cheref-ou'ddine, prince de Bildis, dans I'llated Arzeroume. Trad, du persan et corn-mentes par, t. I-II, [t. I, pt.I, 1868; t.I, pt.II, 1870; t.II, pt.I, 1873; t.II, pt.II, 1875]. Sankt Petersburg.

Encyclopaedia of Islam. (1986). (new ed. Vol. I, p. 1208). Leiden.

Kalimullina, F. G. (2002). Vel'jaminov-Zernov. Tatarskaja jenciklopedija. Kazan: 558-559.

Kalimullina, F. G. (2014). V.V.Vel'jaminov-Zernov kak istorik Kasimovskogo hanstva. Kazan. 
Karimullin, A. K. (1992). U istokov tatarskoj knigi. Kazan.

Materialy dlja istorii Krymskogo hanstva, po rasporjazheniju imperatorskoj Akademii nauk iz Moskovskogo glavnogo arhiva Ministerstva inostrannyh del. (1864). Sankt Peterburg.

Obydennov, M. F. (1986). Tajna ufimskih holmov. Ufa.

Pamjatniki pis'mennosti Vostoka. Sharaf-name. (1967). Perevod, predislovie, primechanija E.I.Vasil'evoj. T.1., Moskva.

Rossijskij gosudarstvennyj istoricheskij arhiv, Sankt-Peterburg (RGIA). F. 733.Op. 121. D. 323. L. 1-10.

Sankt-Peterburgskiy filial Arhiva Rossijskoj Akademii nauk, Fond 2. Opis 1-1859. Delo 5. List $42-44$.

Sovetskaja istoricheskaja jenciklopedija. (1961). (T.1, stb. 416). Moskva.

Umarov, Je. A. (1985). V.V.Vel'jaminov-Zernov - izdatel' slovarja «Abushka». Sovetskaja tjurkologija, 5. Baku: 48.

Usmanov, M. A. (1980). Zavetnaja mechta H.Faizhanova. Povest' o zhizni i dejatel'nosti. Kazan.

Vélïaminof-Zernof, V. (1860; 1862). Scheref-nameh ou histoire des Kourdes, par Scheref, Prince des Bidlis, vol. 1: history of the Kurds, 1860, vol. 2: history of the Ottomans, 1962. Sankt Petersburg.

Velyaminov-Zernov, V. V. (1859). Monety buharskie i hivinskie. Trudy Vostochnogo otdelenija Imperatorskogo Arheologicheskogo obshhestva (Ch. 4, s.328). Sankt Peterburg.

Velyaminov-Zernov, V. V. (1859). O grobnice svjatogo Horhuta na Syr-Dar'e. Trudy Vostochnogo otdelenija Russkogo Arheologicheskogo obshhestva (Ch. IV, s.283-284). Sankt Peterburg.

Velyaminov-Zernov, V. V. (1863). Issledovanie o kasimovskih carjah i carevichah. T.1. Sankt Peterburg.

Velyaminov-Zernov, V. V. (1864a). Issledovanie o kasimovskih carjah i carevichah. T.2. Sankt Peterburg.

Velyaminov-Zernov, V. V. (1864b). Istochniki dlja izuchenija tarhanstva, zhalovannogo bashkiram russkimi gosudarjami. Sankt Peterburg .

Velyaminov-Zernov, V. V. (1866). Issledovanie o kasimovskih carjah i carevichah. T.3. Sankt Peterburg.

Velyaminov-Zernov, V. V. (1868). Slovar' dzhagatajsko-tureckij. Sankt Peterburg.

Velyaminov-Zernov, V. V. (1879). Chetvertyj mezhdunarodnyj s\#ezd orientalistov vo Florencii. Zhurnal Ministerstva narodnogo prosveshhenija (Ch. 201, s.1-12). Sankt Peterburg.

Velyaminov-Zernov, V. V. (2011). Avrasya türkologları sözlügü. Rusya türkologları (XX Yüzyll), (C.1, K.1. S.189-191). Ankara.

Velyaminov-Zernov, V.V. (1887). Issledovanie o kasimovskih carjah i carevichah. T.4. Sankt Peterburg.

Veselovskij, N. I. (1887). V.V.Grigor'ev po ego pis'mam i trudam. 1816-1881. Sankt Peterburg.

Veselovskij, N. I. (1904). V.V.Vel'jaminov-Zernov V.V. Nekrolog. Zhurnal Ministerstva narodnogo prosveshhenija. Ch.352. Sankt Peterburg: 201-212.

Zapiski IAN. (1868). T.13. Sankt Peterburg: 76, 143.

Zapiski IAN. (1869). T.15. Sankt-Peterburg: 120.

Zapiski Imperatorskoj Akademii nauk (Zapiski IAN). (1863). T.3. Sankt Peterburg: 36, 199-200.

Zemlevedenie K. Rittera. (1867). Zhurnal Ministerstva narodnogo prosveshhenija. Ch.34. Sankt Peterburg: 615-635.

\section{Copyrights}

Copyright for this article is retained by the author(s), with first publication rights granted to the journal.

This is an open-access article distributed under the terms and conditions of the Creative Commons Attribution license (http://creativecommons.org/licenses/by/3.0/). 